\title{
Antidiabetic activity of aqueous extract of Sigesbeckia orientalis (St. Paul's Wort) in alloxan-induced diabetes model
}

\author{
Muhammad Asif ${ }^{\odot 1}$, Mohammad Saleem*2, Sobia Yousaf', Malik Saadullah¹, Memoona Zafar ${ }^{1}$, \\ Rizwan Ullah Khan ${ }^{3}$, Alamgeer Yuchi ${ }^{4}$
}

\begin{abstract}
${ }^{1}$ Faculty of Pharmaceutical Sciences, Government College University, Faisalabad, Pakistan, ${ }^{2}$ University College of Pharmacy, University of the Punjab, Lahore, Pakistan, ${ }^{3}$ Department of Pathology, Fatima Memorial Hospital, College of Medicine and Dentistry, Lahore, Pakistan, ${ }^{4}$ College of Pharmacy, University of Sargodha, Sargodha, Pakistan
\end{abstract}

\begin{abstract}
The current study evaluated antidiabetic and antihyperlipidemic activities of aqueous extract of Sigesbeckia orientalis L. (St. Paul's Wort) (AESO) in an alloxan-induced diabetic rat model. Following OECD guidelines safe doses of AESO were assessed in rats for the main study. Serum/bood glucose, $\alpha$-amylase, and lipids levels and histopathological evaluations were conducted to assess antidiabetic and associated antihyperlipidemic efficacies of AESO. AESO was found to be safe up to the dose of $2000 \mathrm{mg} / \mathrm{kg}$. Significant $(p<0.05)$ reduction in glucose and lipids (total cholesterol, triglycerides, low-density lipoproteins) levels was observed in AESO treatment groups. Serum $\alpha$-amylase, high-density lipoproteins, and total body weight was increased significantly $(p<0.05)$ in diabetic rats treated with AESO. Histopathological data showed improvement in hepatocyte and pancreatic $\beta$-cells islets architecture. HPLC analysis identified quercetin, gallic acid, vanillic acid, p-coumaric acid, m-coumaric acid and cinnamic acid in AESO which are suggested to be responsible for observed antihyperglycemic and antihyperlipidemic attributes. Further studies to standardise the extract and evaluation of safety profile in long-term toxicity studies are recommended for safe and effective antidiabetic nutraceuticals development.
\end{abstract}

Keywords: Antidiabetic. Sigesbeckia orientalis L. Alloxan. Antihyperlipidemic. HPLC.

\section{INTRODUCTION}

Management and treatment of chronic disorders is one of the greatest challenges scientific communities facing in this modern era. In spite of major advancements in the healthcare system, scientists are still incapable of uprooting major chronic diseases like diabetes mellitus (DM). DM is a metabolic disorder during which human body loses its ability to regulate blood glucose levels which may be due to an abnormality in insulin production, resistance to peripheral effects of insulin or both and occurring simultaneously with abnormal carbohydrates, fats and proteins metabolism (Ramachandran et al., 2011). It may be asymptomatic or appear with most devastating symptoms like ketoacidosis or non-ketonic hyperosmolar state ultimately resulting in coma. Common symptoms of DM include extensive thirst, polyuria, weight loss,

\footnotetext{
*Correspondence: M. Saleem. University College of Pharmacy, University of the Punjab, Lahore, Pakistan. Tel No: +92-3214289022. E-mail: Saleem2978@hotmail.com
}

polyphagia, inability of body's healing capacity and blurring of vision etc. (WHO, 2016). Physical inactivity and modern food intake habits have multiplied prevalence of DM over the years, which is $67 \%$ higher than estimates of 2004 (Shaw, Sicree, Zimmet, 2010). According to the World Health Organization (WHO) estimates, diabetic patients were estimated to be 108 million in 1980 and now this number has reached up to 422 million. Pakistan is among the top 10 countries (ranking $7^{\text {th }}$ position) which are having high diabetic prevalence. Current prevalence of diabetes in Pakistan is documented to be 7.6-11\% and is claimed to reach up to $15 \%$ by 2030 which will place Pakistan at $4^{\text {th }}$ position in the world (Hussain, Ali, 2016). Majority of diabetes medications have imperfect glycemic control and have side effects including weight gain, diarrhoea, nausea, and lactic acidosis, reflecting the limitations of current pharmacotherapy (Tsang, 2012). The WHO has emphasized on the use of ethanomedicines for diabetic control. According to the reports, more than 1200 plants have been traditionally used for their 
hypoglycemic effects, out of which 800 plants have been scientifically reported to have antidiabetic potential (Pandey et al., 2011). Plants and plant-derived products have additional advantages of safety, low cost, and ease of availability along with their multi-targeting ability due to presence of diverse chemical compounds which may provide synergistic actions against diabetes. Multiple plant extracts/ derived products are available in Asian herbal markets as antidiabetic agents like; "Diabet Guard ${ }^{\mathrm{TM}}$ Granules" is an Indian antidiabetic herbal product containing Azadirachta indica, Eugenia jambolana, Gymnema sylvestre, Momordica charantia, and Tinospora cordifolia as active agents (Aggarwal, Shishu, 2011).

Sigesbeckia orientalis L. (St. Paul's Wort) is annually grown natural herb of family Asteraceae and has been used traditionally for the treatment of multiple ailments (Wang et al., 2011). It is found in tropical, subtropical, temperate zones as well as in Africa and Asia (Wang et al., 2011). It is also used topically for the treatment of syphilis, leprosy, gangrenous ulcers and sores (Khare, 2008). A number of pharmacologically active and useful phytochemical constituents are part of this herb and are suggested to be responsible for its health promoting activities. Bioactive chemical compounds found in aerial parts of $S$. orientalis include sesquiterpene lactone, orientin, and diterpenes. 3, 7-dimethyl quercetin has been reported to be found in abundance in whole plant (Khare, 2008). It has been reported to have anti-inflammatory, analgesic, antirheumatic, antimalarial, antihypertensive, immunosuppressant, anti-snake venom, and antiproliferative (against human endometrial RL-95 cancer cells) activities (Sun, Wang, 2006; Wang et al., 2011; Chang et al., 2015). Traditionally the whole plant is used as a hypoglycemic agent (Marles, Farnsworth, 1995) but to best of our knowledge, there is no scientific study available that reports the antihyperglycemic and antihyperlipidemic activities of $S$. orientalis. Therefore, the current study was designed with an objective to evaluate antidiabetic potential of aqueous extract of $S$. orientalis whole plant in an alloxan-induced diabetic rat model.

\section{MATERIAL AND METHODS}

\section{Plant material and extract preparation}

Aqueous extract of S. orientalis (AESO) whole plant was prepared by maceration. After collection and washing with tap water, the whole plant was dried under shade. Subsequently, dried material was powdered, sieved, macerated in water with occasional shaking and then filtered through grade I Whatmann filter paper. Finally, filtrate was spray dried in vacuum drying apparatus. AESO was obtained in form of a fine (brown colour) powder which was kept in airtight container in fridge at $4{ }^{\circ} \mathrm{C}$ until further experimentation. AESO was dissolved in distilled water for all in vivo studies.

Plant material was collected by Dr. Saadullah from Swat Valley, Pakistan and identified by the expert taxonomist, Dr Altaf Ahmed Dasti, Institute of Pure and Applied Biology, BZU, Multan, Pakistan and specimen no Steward SO231 was allotted for future reference.

\section{Animals}

Albino rats of either sex weighing 150-200g were purchased from the animal house of University of Agriculture, Faisalabad, Pakistan and were kept at animal housing facility of Faculty of Pharmaceutical Sciences, Government College University Faisalabad (GCUF) with free access to routine feed and water ad libitum. The housing environment was set at standard environmental conditions i.e., temperature set at $22 \pm 2{ }^{\circ} \mathrm{C}$ with alternative dark and light cycle of 12 hours. All the in vivo experiments were carried out with the prior of Institutional Animal Ethical Committee of GCUF, Pakistan (Study No. 19599 and Ref.No.GCUF/ERC/1999).

\section{Acute toxicity studies}

The acute oral toxicity study was conducted as per OECD guideline No. 423 for a period of 14 days. Albino rats of either sex were weighed and marked individually for proper observation purpose. They were then kept in Individual cages at room temperature, i.e., $22 \pm 2{ }^{\circ} \mathrm{C}$ and $30 \%$ humidity. Food but not water was withdrawn from all animals overnight prior to AESO administration and 3-4 hours post administration. AESO was administered via oral route at doses of 5, 50, 300 and $2000 \mathrm{mg} / \mathrm{kg}$ in $2 \mathrm{~mL}$ of distilled water. 3 animals were used for each dosing level as recommended by guideline. Changes in skin, eyes, fur and mucous membrane colour were noted along with any sign of tremors, convulsions, salivation, diarrhoea, lethargy and sleep etc. Changes in body weight were recorded before, during and at the end of study (OECD, 2002).

\section{Induction of diabetes}

Diabetes was induced in overnight fasted rats by intraperitoneal injection $(I P)$ of alloxan monohydrate $(150 \mathrm{mg} / \mathrm{kg}$ body weight $)$, freshly prepared in normal saline. $20 \%$ dextrose solution $(\mathrm{w} / \mathrm{v})$ was administered after $6 \mathrm{~h}$ to prevent alloxan-induced hypoglycemia due 
to the massive release of insulin from pancreas. For the next $24 \mathrm{~h}$, rats were maintained on $5 \%$ glucose in drinking water. After $72 \mathrm{~h}$, blood glucose was checked by using Accu-Answer ${ }^{\circledR}$ digital glucose sensor. Animals with blood glucose greater than $200 \mathrm{mg} / \mathrm{dL}$ were selected and allowed to stabilize for 1 week before detailed experimentations (Sornalakshmi et al., 2016).

\section{Oral glucose tolerance test}

Oral glucose tolerance test (OGTT) for AESO was conducted in normal and hyperglycemic rats. Animals were divided into nine groups of 6 animals each $(n=6)$. Four groups were used for OGTT in normal rats and five groups were used for OGTT in diabetic rats. Glibenclamide $(10 \mathrm{mg} / \mathrm{kg})$ was used as standard antidiabetic drug (Table I). Animals were given glucose at concentration of $2 \mathrm{~g} / \mathrm{kg}$ body weight after $1 \mathrm{~h}$ of AESO administration in experimental groups and blood glucose levels were measured by one touch Accu-Answer ${ }^{\circledR}$ digital glucometer at different time interval i.e., 0, 0.5, 1, 2, 3 and $6 \mathrm{~h}$ respectively (Sornalakshmi et al., 2016).

\section{Determination of glucose and other biochemical parameters}

In order to check antidiabetic potential of AESO, blood glucose levels were monitored by one touch AccuAnswer ${ }^{\circledR}$ digital glucometer on day 0, 3, 6, 9, 12 and 14 respectively. Blood samples for other biochemical parameters were collected at the end of the study by sacrificing animals. Gel vacutainers were used to collect blood samples. Collected blood was allowed to coagulate in the refrigerator for 20 minutes, then centrifuged for 3-5 minutes and serum was collected and analysed for total cholesterol (TC), triglycerides (TG), high-density lipoproteins (HDL), low-density lipoproteins (LDL) and serum amylase levels respectively. TC, HDL, TG levels were determined using Crescent diagnostic assay kits following manufacturer recommended methods (CHOD-PAP, phosphotungstic-precipitation and GPO-PAP method respectively). Calorimetric estimation of serum amylases was carried using assay kit of amylase activity. LDL levels were calculated using Friedwald equation given below (Chaudhry et al., 2016).

$$
\mathrm{LDL}(\mathrm{mg} / \mathrm{dL})=\mathrm{TC}-\mathrm{HDL}-\mathrm{TG} / 5
$$

\section{Body weight changes}

Animals were observed for changes in their body weight before starting treatment (day 0 ) and during (day 7 ) and at the end of study (day 14) respectively.

\section{Histopathological examination}

Liver and pancreas of animals were excised for histopathological investigations using Haematoxylin and Eosin (H\&E) stains. Changes in morphology of pancreatic cells and hepatocytes were observed under the microscope using $20 \times$ and $40 \times$ magnifications (Suvarna, Layton, Bancroft, 2012).

\section{Preliminary phytochemical evaluation through HPLC}

Shim-pack CLC-ODS (C-18) reversed phase column (25 x $4.6 \mathrm{~mm}$ ) packed with $5 \mu \mathrm{m}$ diameter particles was used to carry out HPLC analysis. Doubled distilled water with acetic acid (94:6) at $\mathrm{pH} 2.27$ and acetonitrile were

TABLE I -OGTT treatment groups

\begin{tabular}{lll}
\hline Sr. No & Group & Treatment \\
\hline \multicolumn{2}{l}{ Normoglycemic rats } & \\
\hline 1 & Group I (Control) & Received routine feed and normal saline \\
2 & Group II (Glibenclamide $10 \mathrm{mg} / \mathrm{kg})$ & Received routine feed + glibenclamide $(10 \mathrm{mg} / \mathrm{kg})$ \\
3 & Group III (AESO $250 \mathrm{mg} / \mathrm{kg}$ ) & Received routine feed + AESO at dose $250 \mathrm{mg} / \mathrm{kg}$ body weight \\
4 & Group IV (AESO $500 \mathrm{mg} / \mathrm{kg}$ ) & Received routine feed + AESO at dose $500 \mathrm{mg} / \mathrm{kg}$ body weight \\
\hline & Hyperglycemic rats & \\
\hline 5 & Group I (Control) & Normal rats received routine feed + normal saline \\
6 & Group II (Diabetic control) & Diabetic rats received routine feed + normal saline \\
7 & Group III (Glibenclamide $10 \mathrm{mg} / \mathrm{kg})$ & Received routine feed + glibenclamide $(10 \mathrm{mg} / \mathrm{kg})$ \\
8 & Group IV (AESO $250 \mathrm{mg} / \mathrm{kg})$ & Received routine feed + AESO at dose $250 \mathrm{mg} / \mathrm{kg}$ body weight \\
9 & Group V (AESO $500 \mathrm{mg} / \mathrm{kg})$ & Received routine feed + AESO at dose $500 \mathrm{mg} / \mathrm{kg}$ body weight \\
\hline
\end{tabular}


used as mobile phase I and II respectively. Acetonitrile was run as $15 \%$ from $0-15$ minutes, $45 \%$ from $15-30$ minutes and $100 \%$ from $30-45$ minutes. Flow rate of mobile phase was $1 \mathrm{~mL} /$ minute. Recordings were obtained at $280 \mathrm{~nm}$ wavelength using UV-visible detector. Chromatogram was plotted between units of voltage and time in minutes along $\mathrm{x}-$ and $\mathrm{y}$-axis respectively. Compounds were identified by comparing the peaks of separated compounds and reference compounds (Ramachandran et al., 2011).

Compounds were identified by comparing the peak retention times with reference standards. Please see the supplementary file for standards HPLC chromatograms (Figure S1).

\section{Statistical analysis}

Data presented as mean \pm S.E.M of three independent experiments $(\mathrm{n}=3)$. One way analysis of variance (ANOVA), followed by Tukey's Post Hoc test was performed to estimate difference between different groups. A statistical significance criterion was $p<0.05$.

\section{RESULTS}

\section{HPLC characterization of AESO}

HPLC analysis of AESO led to the identification of compounds from flavonoids and phenols family i.e., quercetin, vanillic acid, coumaric acid, and cinnamic acid respectively (Figure 1).

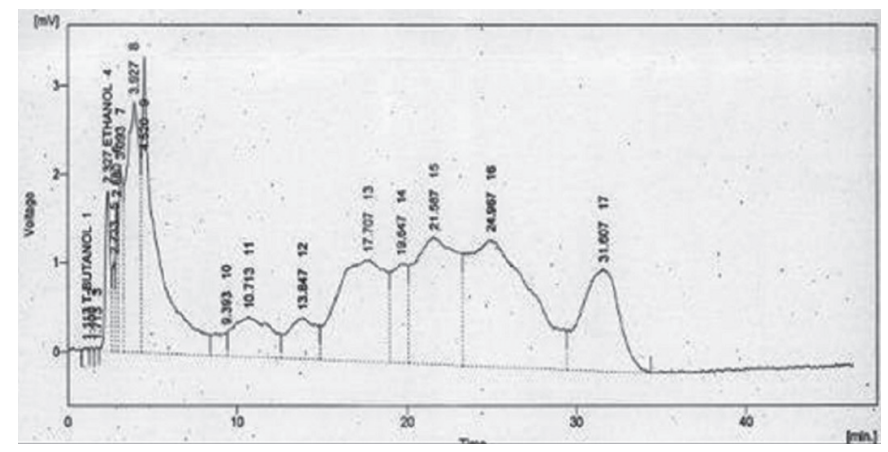

FIGURE 1 - HPLC chromatogram of aqueous extract of Sigesbeckia orientalis. Where peak $7=$ quercetin, peak $9=$ gallic acid, peak $12=$ vanillic acid, peak $13=$ p-coumeric acid, peak $14=$ m-coumeric acid and peak $16=$ cinamic acid.

\section{Acute toxicity assessment of AESO}

Data of oral acute toxicity test (supplementary Table $\mathrm{S} 1)$ showed neither any sign of morbidity nor mortality in animals given single dose of $2000 \mathrm{mg} / \mathrm{kg}$ of AESO.

\section{Hypoglycemic effects of AESO in oral glucose tolerance test (OGTT)}

Significant decrease $(p<0.05)$ in blood glucose levels was observed in normoglycemic rats at $6^{\text {th }} \mathrm{h}$ of glucose administration in AESO-treated animals compared with the control group. While, in hyperglycemic rats, treatment with $500 \mathrm{mg} / \mathrm{kg}$ of AESO significantly $(p<0.05)$ lowered blood glucose levels after $3 \mathrm{~h}$ of glucose administration. Treatment with $250 \mathrm{mg} / \mathrm{kg}$ of AESO showed its significant effects at $6^{\text {th }} \mathrm{h}$ of glucose administration when compared with glucose levels in the control group (Table S2).

\section{Hypoglycemic effects of AESO in Alloxan-induced diabetic rats}

Significant reduction in blood glucose levels was observed in blood samples of animals treated with AESO for 14 days (Table II). No significant changes in levels of glucose were observed in blood samples of animals treated with AESO (250 and $500 \mathrm{mg} / \mathrm{kg}$ ) and glibenclamide $(10 \mathrm{mg} / \mathrm{kg})$ after $24 \mathrm{~h}$ of treatment. After $72 \mathrm{~h}$ of treatment significant decrease $(p<0.05)$ in blood glucose levels was observed in glibenclamide treatment group, while in AESO did not induce significant hypoglycemic effects when compared with glucose levels of diabetic control group. From day 6 to 14 significant $(p<0.05)$ decrease in levels of glucose was observed in blood samples of animals treated with AESO (250 and $500 \mathrm{mg} / \mathrm{kg}$ ) and glibenclamide $(10 \mathrm{mg} / \mathrm{kg})$ respectively when compared with glucose levels in blood samples of diabetic animals (Figure 2)

\section{Antihyperlipidemic effects of AESO in Alloxan- induced diabetic rats}

\section{Total cholesterol}

Significant increase $(p<0.05)$ in serum total cholesterol levels was observed in diabetic animals $(129.33 \pm 4.10 \mathrm{mg} / \mathrm{dL})$ as compared to the control group $(73.50 \pm 1.23 \mathrm{mg} / \mathrm{dL})$ (Table III). Significant reduction $(p<0.05)$ in serum total cholesterol level was observed in animals treated with 250 and $500 \mathrm{mg} / \mathrm{kg}$ of AESO $(113.67 \pm 4.12$ and $75.67 \pm 6.06 \mathrm{mg} / \mathrm{dL})$ and $10 \mathrm{mg} / \mathrm{kg}$ of glibenclamide $(63.17 \pm 7.32 \mathrm{mg} / \mathrm{dL})$, when compared with the diabetic control group $(129.33 \pm 4.10 \mathrm{mg} / \mathrm{dL})$ (Figure 3).

\section{Triglycerides (TG)}

Table III shows changes in serum triglycerides levels in different treatment groups. Significant increase $(p<0.05)$ 
TABLE II - Effect of aqueous extract of Sigesbeckia orientalis on blood glucose levels in control and experimental groups at different days of treatment

\begin{tabular}{|c|c|c|c|c|c|}
\hline \multirow[b]{2}{*}{ Days } & \multicolumn{5}{|c|}{ Groups } \\
\hline & Control & Diabetic control & $\begin{array}{l}\text { Glibenclamide } \\
\text { (10 mg/kg) }\end{array}$ & $\begin{array}{c}\text { AESO } \\
(250 \mathrm{mg} / \mathrm{kg})\end{array}$ & $\begin{array}{c}\text { AESO } \\
(500 \mathrm{mg} / \mathrm{kg})\end{array}$ \\
\hline $\mathbf{0}$ & $72.0 \pm 1.67^{\mathrm{ns}}$ & $69.83 \pm 02.57^{\mathrm{ns}}$ & $79.33 \pm 06.02^{\mathrm{ns}}$ & $70.67 \pm 02.08^{\text {ns }}$ & $71.83 \pm 04.19^{\mathrm{ns}}$ \\
\hline 1 & $72.5 \pm 1.57^{* * *}$ & $473.67 \pm 56.58^{\mathrm{ns}}$ & $368.50 \pm 56.15^{\mathrm{ns}}$ & $433.33 \pm 39.62^{\mathrm{ns}}$ & $414.33 \pm 43.47^{\mathrm{ns}}$ \\
\hline 3 & $72.0 \pm 2.84^{* * *}$ & $472.00 \pm 58.17$ & $327.67 \pm 67.96^{*}$ & $384.67 \pm 46.93$ & $375.17 \pm 41.08$ \\
\hline 6 & $73.1 \pm 2.51^{* * *}$ & $474.00 \pm 56.26$ & $284.00 \pm 69.67^{*}$ & $308.83 \pm 29.76^{*}$ & $292.67 \pm 37.49^{* * *}$ \\
\hline 9 & $79.83 \pm 6.27^{* * *}$ & $471.50 \pm 53.62$ & $204.33 \pm 56.13^{\text {****}}$ & $258.33 \pm 21.15^{* *}$ & $209.00 \pm 18.94^{* * * *}$ \\
\hline 12 & $72.17 \pm 1.82^{* * *}$ & $474.50 \pm 53.68$ & $162.83 \pm 42.08^{* * * *}$ & $224.17 \pm 18.38^{* * * *}$ & $129.83 \pm 12.99^{* * * *}$ \\
\hline 14 & $71.67 \pm 2.68^{* * *}$ & $474.67 \pm 54.79$ & $115.17 \pm 25.68^{* * * *}$ & $158.50 \pm 19.04^{* * * *}$ & $90.67 \pm 05.31^{* * * *}$ \\
\hline
\end{tabular}

Values are expressed as mean \pm SEM. Comparison was made between glucose levels in blood samples of alloxan-induced diabetic rats and AESO and glibenclamide treated animals. At day 0 and 1 no significant change in blood glucose levels was observed in any treatment group. Blood glucose levels in normal healthy rats remained significantly lower throughout the study. Where ns $=$ non-significant, $*=p<0.25, * *=p<0.01, * * *=p<0.001$ and Diabetic control = Alloxan-induced diabetic rats $(150 \mathrm{mg} / \mathrm{kg})$ respectively.

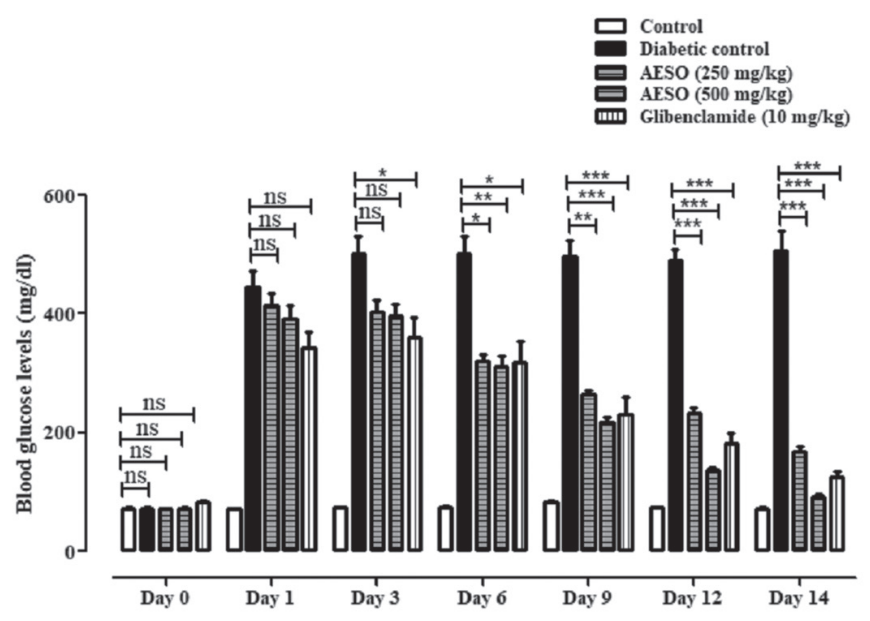

FIGURE 2 - Effect of aqueous extract of Sigesbeckia orientalis on blood glucose levels in control and experimental groups at different days of treatment. Comparison was made between glucose levels in blood samples of alloxan-induced diabetic rats and AESO and glibenclamide treated animals. At day 0 and 1 no significant change in blood glucose levels was observed in any treatment group. Blood glucose levels in normal healthy rats remained significantly lower throughout the study. Where ns $=$ non-significant, $*=\mathrm{p}<0.25, * *=\mathrm{p}<0.01, * * *=\mathrm{p}<0.001$ and Diabetic control = Alloxan-induced diabetic rats $(150 \mathrm{mg} / \mathrm{kg})$ respectively.

in serum triglycerides was observed in alloxan-induced diabetic rats $(118.33 \pm 7.00 \mathrm{mg} / \mathrm{dL})$ when compared with the control group $(72.83 \pm 1.70 \mathrm{mg} / \mathrm{dL})$. When compared with diabetic control group $(118.33 \pm 7.00 \mathrm{mg} / \mathrm{dL})$, significant reduction $(p<0.05)$ in triglyceride levels was observed in serum samples of animal treated with 250 and 500 $\mathrm{mg} / \mathrm{kg}$ of AESO $(98.67 \pm 2.76$ and $55.00 \pm 5.22 \mathrm{mg} / \mathrm{dL})$ and $10 \mathrm{mg} / \mathrm{kg}$ of glibenclamide $(73.67 \pm 14.70 \mathrm{mg} / \mathrm{dL})$ respectively.

\section{High-density lipoproteins (HDL)}

Significant reduction in serum HDL levels was observed in alloxan-induced diabetic rats $(6.50 \pm 1.18 \mathrm{mg} / \mathrm{dL})$ when compared with the control group $(17.17 \pm 0.60 \mathrm{mg} / \mathrm{dL})$. Significant increase $(p<0.05)$ in levels of HDL was observed in serum samples of animals treated with 250 and $500 \mathrm{mg} / \mathrm{kg}$ of AESO $(11.67 \pm 1.12$ and $16.00 \pm 0.93 \mathrm{mg} / \mathrm{dL})$ and $10 \mathrm{mg} / \mathrm{kg}$ of glibenclamide $(14.00 \pm 0.77 \mathrm{mg} / \mathrm{dL})$ and normal group $(17.17 \pm 0.60 \mathrm{mg} / \mathrm{dL})$ when compared with HDL serum levels in diabetic rats (Table III and Figure 3).

\section{Low-density lipoproteins (LDL)}

Significant increase $(p<0.05)$ in serum levels of LDL was observed in alloxan-induced diabetic rats $(74.17 \pm 2.15 \mathrm{mg} / \mathrm{dL})$ when compared with normal control group $(40.67 \pm 2.06 \mathrm{mg} / \mathrm{dL})$. Whereas, significant reduction $(p<0.05)$ in LDL levels in serum samples of rats treated with 250 and $500 \mathrm{mg} / \mathrm{kg}$ of AESO $(49.50 \pm 0.96$ and $38.50 \pm 2.11 \mathrm{mg} / \mathrm{dL})$ and $10 \mathrm{mg} / \mathrm{kg}$ of glibenclamide $(44.17 \pm 1.11 \mathrm{mg} / \mathrm{dL})$ was observed when compared with serum LDL levels of rats in diabetic group $(74.17 \pm 2.15 \mathrm{mg} / \mathrm{dL})$ (Table III and Figure 3). 
TABLE III - Effect of aqueous extract of Sigesbeckia orientalis on total cholesterol, triglycerides, low density lipoproteins and high density lipoprotein levels in different treatment groups

\begin{tabular}{lcccc}
\hline Treatments & \multicolumn{4}{c}{ Parameters (mg/dL) } \\
\cline { 2 - 5 } & TC & TG & LDL & HDL \\
\hline Control & $73.50 \pm 1.23^{* * *}$ & $72.83 \pm 1.70^{* * *}$ & $40.67 \pm 2.06^{* * *}$ & $17.17 \pm 0.60^{* * *}$ \\
Diabetic control & $129.33 \pm 4.1$ & $118.33 \pm 7.00$ & $74.17 \pm 2.15$ & $6.50 \pm 1.18$ \\
Glibenclamide $(10 \mathrm{mg} / \mathrm{kg})$ & $63.17 \pm 7.32^{* * *}$ & $73.67 \pm 14.70^{* * * *}$ & $44.17 \pm 1.11^{* * *}$ & $14.00 \pm 0.77^{* * *}$ \\
AESO $(250 \mathrm{mg} / \mathrm{kg})$ & $113.67 \pm 4.12^{*}$ & $98.67 \pm 2.76^{* *}$ & $49.50 \pm 0.96^{* * *}$ & $11.67 \pm 1.12^{* * *}$ \\
AESO (500 $\mathrm{mg} / \mathrm{kg})$ & $75.67 \pm 6.06^{* * *}$ & $55.00 \pm 5.22^{* * *}$ & $38.50 \pm 2.11^{* * *}$ & $16.00 \pm 0.93^{* * *}$ \\
\hline
\end{tabular}

Values are expressed as mean \pm SEM. Comparison was made between lipids levels in serum samples of alloxan-induced diabetic rats and $\mathrm{AESO}$ and glibenclamide treated animals Where $\mathrm{TC}=$ Total cholesterol, $\mathrm{TG}=$ Triglycerides, $\mathrm{LDL}=\mathrm{Low}$ density lipoproteins, $\mathrm{HDL}=$ High density lipoproteins and Diabetic control = Alloxan-induced diabetic rats $(150 \mathrm{mg} / \mathrm{kg})$.

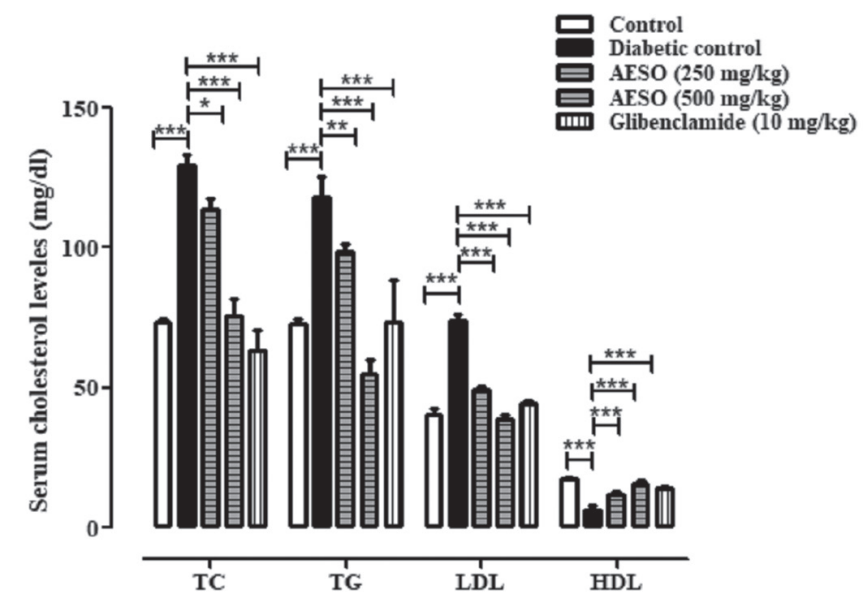

FIGURE 3 - Effect of aqueous extract of Sigesbeckia orientalis on total cholesterol, triglycerides, low density lipoproteins and high density lipoprotein levels in different treatment groups. Comparison was made between lipids levels in serum samples of alloxan-induced diabetic rats and AESO and glibenclamide treated animals Where $\mathrm{ns}=$ non-significant, $*=\mathrm{p}<0.25, * *$ $=\mathrm{p}<0.01, * * *=\mathrm{p}<0.001, \mathrm{TC}=$ Total cholesterol, $\mathrm{TG}=$ Triglycerides, $\mathrm{LDL}=$ Low density lipoproteins, $\mathrm{HDL}=$ High density lipoproteins and Diabetic control = Alloxan-induced diabetic rats $(150 \mathrm{mg} / \mathrm{kg})$.

\section{Serum $\alpha$-amylase}

Serum levels of $\alpha$-amylase in control, diabetic, glibenclamide, AESO 250 and $500 \mathrm{mg} / \mathrm{kg}$ treated groups were $516.83 \pm 66.30,220.67 \pm 51.90,536.17 \pm 101.16$, $398.00 \pm 54.18$ and $553.83 \pm 45.06$ units/L respectively. Alloxan-indiced diabetic rats showed significant reduction $(p<0.05)$ in serum amylase levels. Whereas, increase in serum amylase level was observed in animals treated with $500 \mathrm{mg} / \mathrm{kg}$ of AESO and was comparable to both positive (glibenclamide treated) and control (vehicle treated) groups.

\section{Changes in body weights}

Diabetic rats showed a $16 \%$ decrease in body weight as compared with initial weight, whereas, increase in body weight was observed in diabetic animals treated with 10 $\mathrm{mg} / \mathrm{kg}$ of glibenclamide (14\%) and $250 \mathrm{mg} / \mathrm{kg}(7 \%)$ and $500 \mathrm{mg} / \mathrm{kg}(15 \%) \mathrm{mg} / \mathrm{kg}$ of AESO for 14 days (Table S3) respectively.

\section{Histopathological observations}

\section{Histopathology of liver}

Figure 4 shows effects of different treatments on the morphology of liver cells. Mild sinusoidal dilation with minor necrosis was observed in tissue slides of animals treated with $250 \mathrm{mg} / \mathrm{kg}$ of AESO (Figure 4D). Treatment with $500 \mathrm{mg} / \mathrm{kg}$ of AESO showed normal hepatocytes with lobular regeneration (Figure 4E).

\section{Histopathology of pancreas}

Histopathological evaluation of pancreas of normal rats showed normal islets cell morphology and architecture (Figure 5). Pancreas of rats in the diabetic group showed necrotic islets cells with dilated acini and shrinkage. Morphology of pancreas in glibenclamide-treated rats showed increase in islets size and proliferating beta cells and normal pancreatic architecture. Morphology of pancreas in rats treated with $250 \mathrm{mg} / \mathrm{kg}$ of AESO showed improved islets structure with minimal necrosis and relatively proliferating cells while at $500 \mathrm{mg} / \mathrm{kg}$ large patches of highly proliferating beta cells with normal pancreatic architecture was observed (Figure 5).

\section{DISCUSSION}

Diabetes mellitus (DM) is an endocrine disorder 

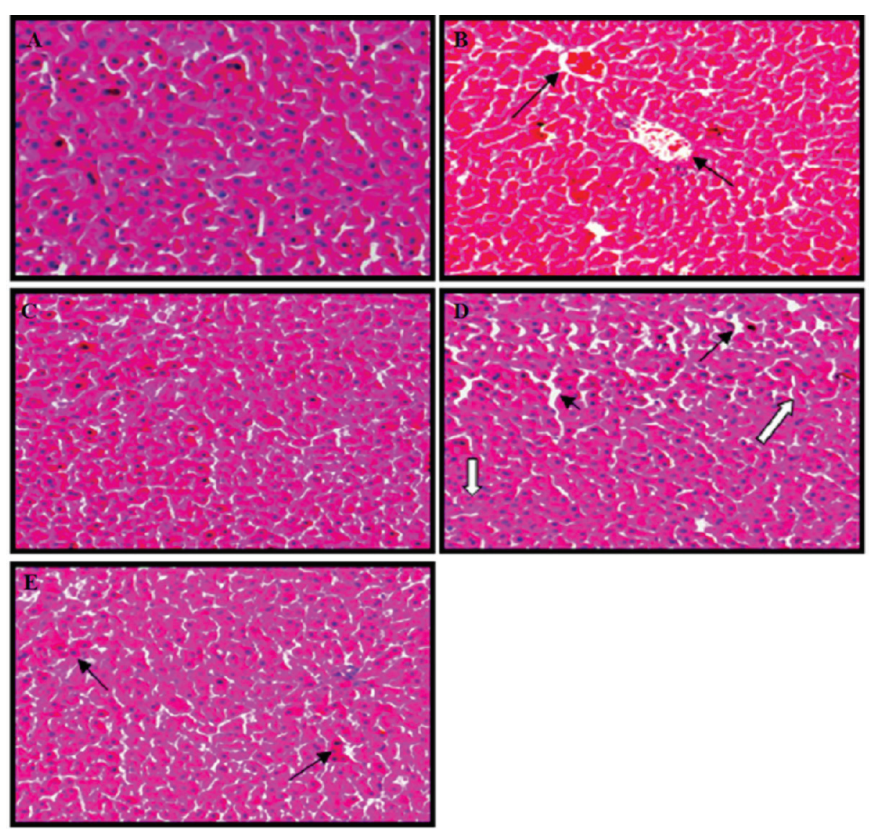

FIGURE 4 - Photomicrographs of effect of different treatments on liver architecture. $\mathrm{A}=$ liver of rats in control group showing normal hepatocytes architecture. $\mathrm{B}=$ photomicrograph of rat liver of diabetic group showing cell necrosis along with lymphocytes infiltration and sinusoidal dilation with the help of arrows. $\mathrm{C}=$ photomicrograph of rat liver in glibenclamide group showing almost same morphology as normal group with normal hepatocytes architecture. $\mathrm{D}=$ photomicrograph of rat liver in AESO 250 group showing improved hepatocyte architecture with mild sinusoidal dilation and minimal necrosis. Black arrows are showing sinusoidal dilations while white bold arrows are depicting improved hepatocyte architecture. $\mathrm{E}=$ photomicrograph of rat liver in AESO 500 group showing normal hepatocytes same as normal control with lobular regeneration (H \& E stain, X20 \& 40).

responsible for approximately 3 million deaths worldwide. It is caused due to an abnormality in metabolic processes either due to reduced insulin production, suppressed insulin actions or both happening at the same time (WHO, 2016). Persistent hyperglycemia in DM leads to multiple microvascular and macrovascular complications affecting several organs, including muscle, skin, heart, brain, and kidneys (Fowler, 2011). According to some estimates, by year 2030, DM will be the $7^{\text {th }}$ leading cause of mortality globally. It has victimized about 422 million people in 2014 (Shaw, Sicree, Zimmet, 2010). Before 70 years of age, $50 \%$ of deaths are due to persistent hyperglycemia and its related complications. Majority of diabetic cases i.e., $92 \%$ are recorded in lower economy countries. According to $\mathrm{WHO}$, Pakistan is standing at $7^{\text {th }}$ position in the list of high diabetic prevalence countries indicating need of urgent steps to address this chronic issue (WHO, 2016).

Treatment of diabetes with conventional drugs
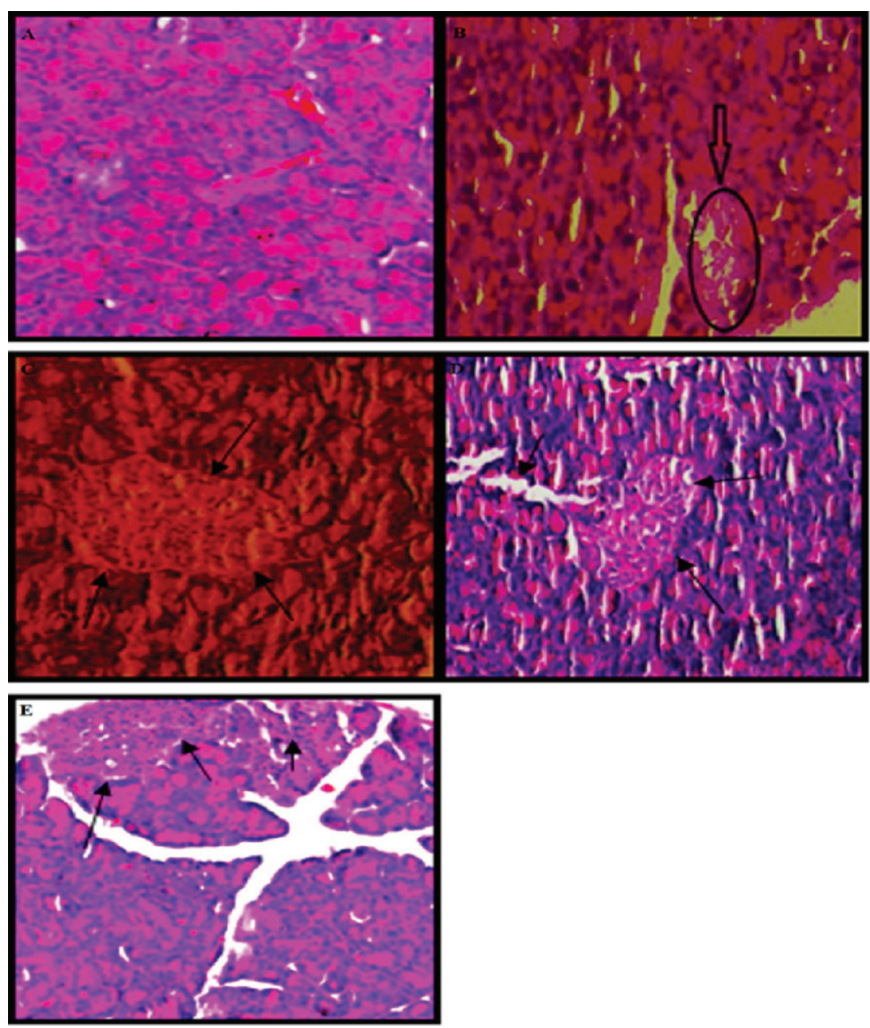

FIGURE 5 - Pancreas of control group showing normal islet cell morphology and architecture. $\mathrm{B}=$ pancreas of diabetic control group showing necrotic islet cells in circle with dilated acini and islet shrinkage. $\mathrm{C}=$ pancreas of glibenclamide-treated group showing increased islet size and proliferating beta cells (black arrows) and normal pancreatic architecture (bold arrows). $\mathrm{D}=$ pancreas of AESO $250 \mathrm{mg} / \mathrm{kg}$ treatment group showing improved islet structure with minimal necrosis and relatively proliferating cells. $\mathrm{E}=$ pancreas of AESO $500 \mathrm{mg} / \mathrm{kg}$ treatment group showing large patches of highly proliferating beta cells with normal pancreatic architecture. Bold arrows show normal cell architecture while black arrows show highly proliferating islet (H \& E stain, X20 \& 40).

is very expensive and chances of side effects are high. Phytochemicals obtained from medicinal plants offer a promising alternative for the development of new therapeutic agents against DM. Most health-promoting phytochemicals obtained from natural products include flavonoids, terpenoids, cardiac glycosides, alkaloids, and steroids respectively (Ajiboye, Asekun, Familoni, 2016). Out of these secondary metabolites polyphenols, in particular, flavonoids are suggested as better therapeutic agents in the management of DM and its chronic complications (Marella, 2017).

The current study was designed to explore the antidiabetic and antihyperlipidemic activities of aqueous extract of Sigesbeckia orieltalis L. in an alloxan-induced diabetic rat model. Before commencement of the main 
study, a preliminary toxicological study was conducted in order to select the safe doses for antidiabetic evaluations. The first priority in herbal research is an assessment of safety profile of herbal product and setting up a criterion for selecting a safe dose for human use (Yehya et al., 2018). Safety data obtained, showed that AESO was non-toxic up to the dose of $2000 \mathrm{mg} / \mathrm{kg}$ in normal healthy rats. Therefore, $1 / 4^{\text {th }}$ of this dose i.e., $500 \mathrm{mg} / \mathrm{kg}$ and below were selected for further detailed studies. Oral glucose tolerance test is conducted to determine ability of body to utilize glucose as well as apparent insulin release and insulin resistance in various clinical situations (Sornalakshmi et al., 2016). In the present study, significant decrease $(p<0.05)$ in blood glucose levels was observed in alloxan-induced diabetic rats treated with AESO. More prominent antihyperglycemic effects were observed in animals treated with $500 \mathrm{mg} /$ $\mathrm{kg}$ of AESO. This data demonstrates that AESO possibly improved insulin release from beta cells and prevented impaired glucose tolerance, which are two most important characteristics of DM (Chaudhry et al., 2016).

Alloxan is known to induce a hyperglycemia by destroying $\beta$-cells of pancreas via redox-mediated mechanisms. Auto-oxidation of glucose in hyperglycemic state can lead to lipid peroxidation, altered antioxidant defense mechanisms leading to further dysfunctions in glucose metabolism and are known to be mediated by reactive oxygen species (ROS) (Chaudhry et al., 2016). In vitro antioxidant and anti-glycation activities of Siegesbeckia orientalis has recently been reported (Hung et al., 2017). Moreover, flavonoids have been shown to produce their antidiabetic effects through enhancement of insulin secretion via regeneration of pancreatic $\beta$-cells, enhancement of insulin mediated glucose uptake by target cells, inhibition of aldose reductase and increased uptake of $\mathrm{Ca}^{2+}$ respectively (Marella, 2017). HPLC analysis of AESO indicated the presence of compounds from flavonoids and phenols family i.e., quercetin, vanillic acid, coumaric acid and cinnamic acid respectively (Figure 1). Majority of these phytochemicals have been indicated to have antidiabetic attributes via different mechanisms (Adefegha et al., 2015; Amalan et al., 2016; Choi et al., 2010; Chang et al., 2015; Fachriyah, et al., 2017; Hafizur et al., 2015). Thus on the basis of these findings, it is proposed that multi-components of AESO having antioxidant and insulin-secreting and $\beta$-cells protective attributes are proposed to be responsible for observed hypoglycemic effects.

Hyperglycemia and hyperlipidemia are two important characteristics of diabetes mellitus. Persistent hyperglycemia is known to be associated with altered lipid profile and changes in serum enzymes and total body weight etc. (Kumar, Kumar, Prakash, 2011). AESO treatment improved lipid profile by lowering serum TC, TG, and LDL and increasing serum HDL levels respectively. This observation suggests that changes in cholesterol absorption/ biosynthesis or changes in lipoprotein metabolism are suggested to be responsible for antihyperlipidemic effects of AESO in alloxan-induced diabetic rats. Taken together, these two observations i.e., antidiabetic and lipid-lowering activities suggest that AESO use may be able to prevent multiple diabetesassociated cardiovascular diseases. Data of the current study is supported by another research report where similar types of changes in blood glucose and lipid profile were observed in alloxan-induced diabetic rats after administration of plant extract (Chaudhry et al., 2016).

Histopathological evaluations showed alloxan induced degenerative changes in liver and pancreas of animals, which were in accordance with previous studies (Shah, Khan, 2014). Pancreas and liver of rats treated with AESO showed reversal of damages caused by alloxaninduced hyperglycemia and resulted in normal liver and pancreatic architecture.

Decrease in body weight due to muscle wasting is one of the characteristics of alloxan-induced diabetes. Moreover, change in body weight is used as an indicator of toxicity, as $10 \%$ or more decrease in body weight when compared with initial weight highlights the toxic nature of plant extract/ isolated compound or synthetic drugs (Chaudhry et al., 2016; Yehya et al., 2018). In the current study, increase in body weight in AESO-treated diabetic rats was observed, suggesting relatively safe nature of water extract.

\section{CONCLUSION}

The current study highlights for the first time antidiabetic and antihyperlipidemic potential of aqueous extract of Sigesbeckia orientalis against alloxan-induced diabetes. Multicomponent synergism is suggested to be responsible for the observed effects. Further studies to standardise extract and to establish the safety profile of extract in chronic models before commencement of clinical trials are warranted.

\section{CONFLICT OF INTEREST}

Authors declare no conflict of interest in the present work.

\section{ACKNOWLEDGEMENT}

We would like to acknowledge Faculty of Pharmaceutical Sciences, Government College University 
Faisalabad, for providing the facilities to conduct this study. Portion of this project was also supported by the Higher Education Commission of Pakistan Research Grant (No: 21-1828/SRGP/R\&D/HEC/2018).

\section{REFERENCES}

Adefegha SA, Oboh G, Ejakpovi II, Oyeleye SI. Antioxidant and antidiabetic effects of gallic and protocatechuic acids: a structurefunction perspective. Comp Clin Path. 2015;24(6):1579-85.

Aggarwal N, Shishu. A review of recent investigations on medicinal herbs possessing anti-diabetic properties. J Nutrition Disorder Ther. 2011;1(102):2.

Ajiboye AT, Asekun OT, Familoni OB. The role of plant natural products in diabetes drug discovery and development: A report with focus on Nigerian biodiversity. Endocrine Abstracts. 2016;43:OC46.

Amalan V, Vijayakumar N, Indumathi D, Ramakrishnan A. Antidiabetic and antihyperlipidemic activity of p-coumaric acid in diabetic rats, role of pancreatic GLUT 2: In vivo approach. Biomed Pharmacother. 2016;84:230-36.

Chang WC, Wu JS, Chen CW, Kuo PL, Chien HM, Wang YT, Shen SC. Protective effect of vanillic acid against hyperinsulinemia, hyperglycemia and hyperlipidemia via alleviating hepatic insulin resistance and inflammation in HighFat Diet (HFD)-fed rats. Nutrients. 2015;7(12):9946-59.

Chaudhry SR, Akram A, Aslam N, Asif M, Wajid M, Kinfe T, Jabeen Q, Muhammad S. Antidiabetic and antidyslipidemic effects of Heliotropium strigosum in rat models of Type I and Type II diabetes. Acta Pol Pharm. 2016;73(6):1575-1586.

Choi H, Kim J, Kim J, Joo H, Kang Y. Hypoglycemic effect of quercetin in animal models of diabetes. FASEB J. 2010;24(1):722.22.

Fachriyah E, Eviana I, Eldiana O, Amaliyah N, Sektianingrum AN. Antidiabetic activity from gallic acid encapsulated nanochitosan. IOP Conf Ser Mater Sci Eng. 2017;172:012042.

Fowler MJ. Microvascular and macrovascular complications of diabetes. Clin Diabetes. 2011;29(3):116-22.

Hafizur RM, Hameed A, Shukrana M, Raza SA, Chishti S, Kabir N, Siddiqui RA. Cinnamic acid exerts anti-diabetic activity by improving glucose tolerance in vivo and by stimulating insulin secretion in vitro. Phytomed. 2015;22(2):297-300.
Hung WC, Ling XH, Chang CC, Hsu HF, Wang EW, Lee YC, Luo C, Lee YT, Houng JY. Inhibitory effects of Siegesbeckia orientalis extracts on advanced glycation end product formation and key enzymes related to metabolic syndrome. Molecules. 2017;22(10):E1785.

Hussain A, Ali I. Diabetes mellitus in Pakistan: A major public health concern. Arch Pharma Pract. 2016;7(1):30.

Khare CP. Indian medicinal plants: an illustrated dictionary, Springer Science \& Business Media; 2008.

Kumar S, Kumar V, Prakash O. Antidiabetic, hypolipidemic and histopathological analysis of Dillenia indica (L.) leaves extract on alloxan induced diabetic rats. Asian Pac J Trop Biomed. 2011;4(5):347-52.

Marella S. Flavonoids-the most potent poly-phenols as antidiabetic agents: an overview. Mod Appro Drug Des. 2017;11(3):MADD.000513.

Marles RJ, Farnsworth NR. Antidiabetic plants and their active constituents. Phytomed. 1995;2(2):137-89.

OECD. Test No. 423: Acute Oral toxicity - Acute Toxic Class Method, OECD Publishing; 2002.

Pandey A, Tripathi P, Pandey R, Srivatava R, Goswami S. Alternative therapies useful in the management of diabetes: A systematic review. J Pharm Bioallied Sci. 2011;3(4):504.

Ramachandran S, Asokkumar K, Maheswari MU, Ravi T, Sivashanmugam A, Saravanan S, et al. Investigation of antidiabetic, antihyperlipidemic, and in vivo antioxidant properties of Sphaeranthus indicus Linn. in type 1 diabetic rats: an identification of possible biomarkers. Evid Based Complement Alternat Med. 2011;2011:pii:571721.

Shah NA, MR Khan. Antidiabetic effect of Sida cordata in alloxan induced diabetic rats. Biomed Res Int. 2014;2014:671294.

Shaw JE, Sicree RA, Zimmet PZ. Global estimates of the prevalence of diabetes for 2010 and 2030. Diabetes Res Clin Pract. 2010;87(1):4-14.

Sornalakshmi V, Tresina Soris P, Paulpriya K, Packia Lincy M, Mohan VR. Oral Glucose Tolerance Test (OGTT) in normal control and glucose induced hyperglycemic rats with hedyotis leschenaultiana DC. Int J Tox Pharmacol Res. 2016;8(1);59-62. 
Sun HX, Wang H. Immunosuppressive activity of the ethanol extract of Siegesbeckia orientalis on the immune responses to ovalbumin in mice." Chem Biodivers. 2006;3(7):754-61.

Suvarna KS, Layton C, Bancroft JD. Bancroft's Theory and Practice of Histological Techniques E-Book, Elsevier Health Sciences; 2012.

Tsang MW. The management of type 2 diabetic patients with hypoglycaemic agents.” ISRN Endocrinol. 2012;2012:478120.

Wang JP, Zhou YM, Ye YJ, Shang XM, Cai YL, Xiong CM, Wu YX, Xu HX. Topical anti-inflammatory and analgesic activity of kirenol isolated from Siegesbeckia orientalis. J Ethnopharmacol. 2011;137(3):1089-94.
WHO. World Health Statistics 2016: Monitoring Health for the SDGs Sustainable Development Goals, World Health Organization; 2016.

Yehya AHS, Asif M, Kaur G, Hassan LEA, Al-Suede FSR, Abdul Majid AMS, Oon CE. Toxicological studies of Orthosiphon stamineus (Misai Kucing) standardized ethanol extract in combination with gemcitabine. J Adv Res. 2018. doi. org/10.1016/j.jare.2018.05.006.

Received for publication on $07^{\text {th }}$ June 2018 Accepted for publication on $24^{\text {th }}$ September 2018 